Research Article

\title{
A GEOLOGICAL AND PETROLOGICAL OVERVIEW OF THE HISTORY OF KIRA MOUNTAIN: AN APPROACH TO THE SIMILARITY AND DIFFERENCE OF KARACADAG
}

\author{
Süleyman POLAT ${ }^{*}$, Hakan ÇOBAN ${ }^{2}$, Şemsettin CARAN ${ }^{3}$
}

The volcanism of Kira Mountain, at south of the Bitlis Zagros suture zone (BZK), was erupted from different joint systems by young extensional tectonic regime. The main geological and petrographic features of the Late Miocene Kira Mountain volcanics were investigated as well as the major oxide, trace element and rare earth element geochemical characteristics. The Kira Mountain volcanic products are classified as basanite, tephrite and trachybasalt and show alkaline character above the alkaline-subalkaline separation line. Nonetheless, the peripherals associated with these volcanics starts with the Miocene aged Şelmo Formation. This formation is accompanied by Oligocene Germik Formation and Eocene Gercus Formations. The Karacadag volcanics are adjacent to the Lower, Middle and Late-Cambrian Sadan, Koruk and Sosink Formations, respectively, predominantly the Precambrian Derik Formation. In addition to these formations, Late Cretaceous Karababa and Karbogaz Formations, Late Cretaceous-Paleocene Germav Formation, Eocene Midyat Formation and Eocene Şelmo Formations are also contiguous. The phenocrysts of the Karacadag volcanics include olivine, clinopyroxene, plagioclase and opaque minerals. In the Kira Mountain volcanics, olivine, plagioclase and opaque minerals are accompanied by sanidine and pyroxene. As reported by the geochemical and petrographical studies, The Karacadag volcanics are mainly classified as basalt and trachy-basalt, tephrite, basanite and hawaiite. Moreover these lavas are mainly alkaline and present subalkaline transition. The Karacadag volcanics erupted in three different stages with different phases, and the Kira mountain volcanics were found to be identical with the Siverek stage.

Key words: Kira Mount, Batman, Karacadag, basalt

\section{Introduction}

After the closing of the Tethys Ocean in the Middle Miocene (approximately 11-12 Ma, [13, 14, 15]), the deformation and compression effect in Anatolia, which started with the Arabian plate dipping under the Eurasian plate, continues effectively today. As a result of this collision to the north of the Bitlis-Zagros suture zone (BZK), volcanic units such as Mount Ararat, Mount Nemrut, Mount

\footnotetext{
1 Department of Geological Engineering, Batman University, Batman, Turkey, (suleyman.polat@batman.edu.tr) https://orcid.org/0000-0001-9726-3840

2 Department of Civil Engineering, Bitlis Eren University, Bitlis, Turkey, (hcoban@ @eu.edu.tr) (iD) https://orcid.org/0000-0002-96146818

3 Department of Geology Engineering, Süleyman Demirel University, Isparta, Turkey, (semsettincaran@sdu.edu.tr) https://orcid.org/0000-0001-6889-6024
} 
Suphan and Mount Tendurek have developed within the Erzurum-Kars Plateau. In the south of BZK, the Late Miocene Kıra Mountain, which has a limited distribution compared to the Karacadag volcanics and approximately $75 \mathrm{~km}$ to the east (Figure 1), has a long arc shape. Şelmo Formation (Miocene; conglomerate, sandstone, shale, siltstone, etc.), Germik Formation (Oligocene; shale, dolomite and gypsum) and Gercus Formations (Eocene; conglomerate, sandstone and claystone) were covered by the volcanics of the Kira Mountain.

Another volcanic unit in the south of BZK is Karacadag, which has continued its activity in the Late Miocene-Holocene (approximately $11 \mathrm{Ma}-0,01 \mathrm{Ma}$ ), the largest volcanic complex in Anatolia (Figure 2). The neighboring units and geological features of Karacadag begin with Derik Group formations from old to young. Derik Group formations are known as Telbesmi (Precambrian; andesitic intercalated sandstones), Sadan (Lower Cambrian; sandstone mainly with shale alternation), Koruk (Middle Cambrian; limestone, dolomite, dolomitic limestone) and Sosink (Middle- Late Cambrian; sandstone-weighted, occasionally marl and shale alternation) outcropping in different terrains throughout the region. These formations are accompanied by Karababa (Mardin group member, Late Cretaceous; limestone, dolomite, dolomitic limestone), Karbogaz (Adiyaman group member, Late Cretaceous; limestone, occasionally chert band limestone), Germav (Sirnak Group member, Late Cretaceous-Paleocene; marl, shale, sandstone intercalation), Hoya (Midyat Group member, Eocene; limestone and dolomite intercalations) and Şelmo (Silvan Group member, Miocene; milstone, shale, sandstone) formations $[2,5,7,8,16,17]$.

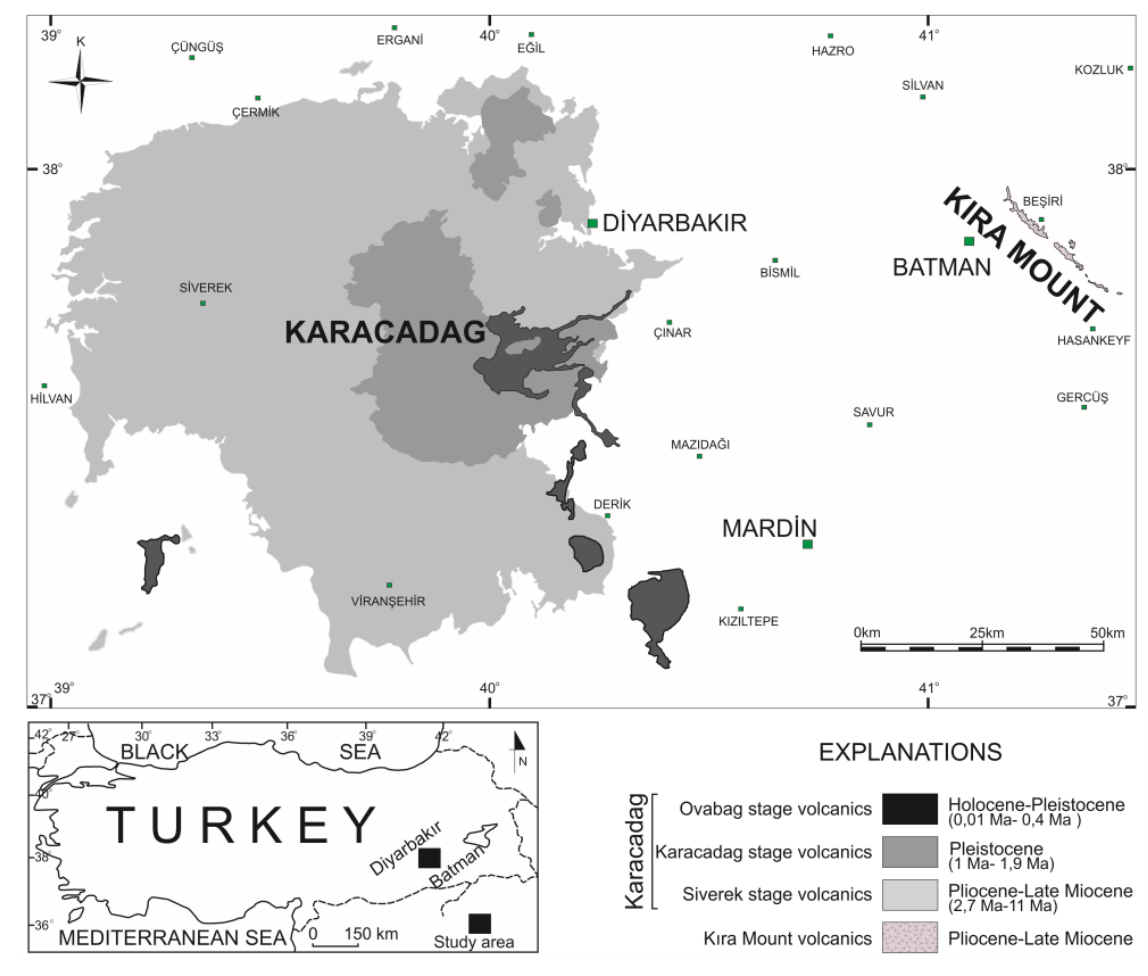

Figure 1 Mapping of Kura Mount and Karacadag in Southeast Anatolia and the spread of two volcanism (The dispersion of Karacadag volcanism is modified from [12])

The Kira Mountain lavas, which can be traced from Batman center, erupted Eocene aged limestones (Hoya formation), sedimentary rocks with Oligocene gypsum-shale-evaporites (Germik formation) and Miocene aged conglomerate-claystone-shales (Şelmo formation) along the stretching 
cracks. In this study, it is aimed to present the geochemical and petrographical data of the Kura Mountain and the Karacadag volcanism. Additionally, the mantle resource areas are evaluated in the light of the available data.

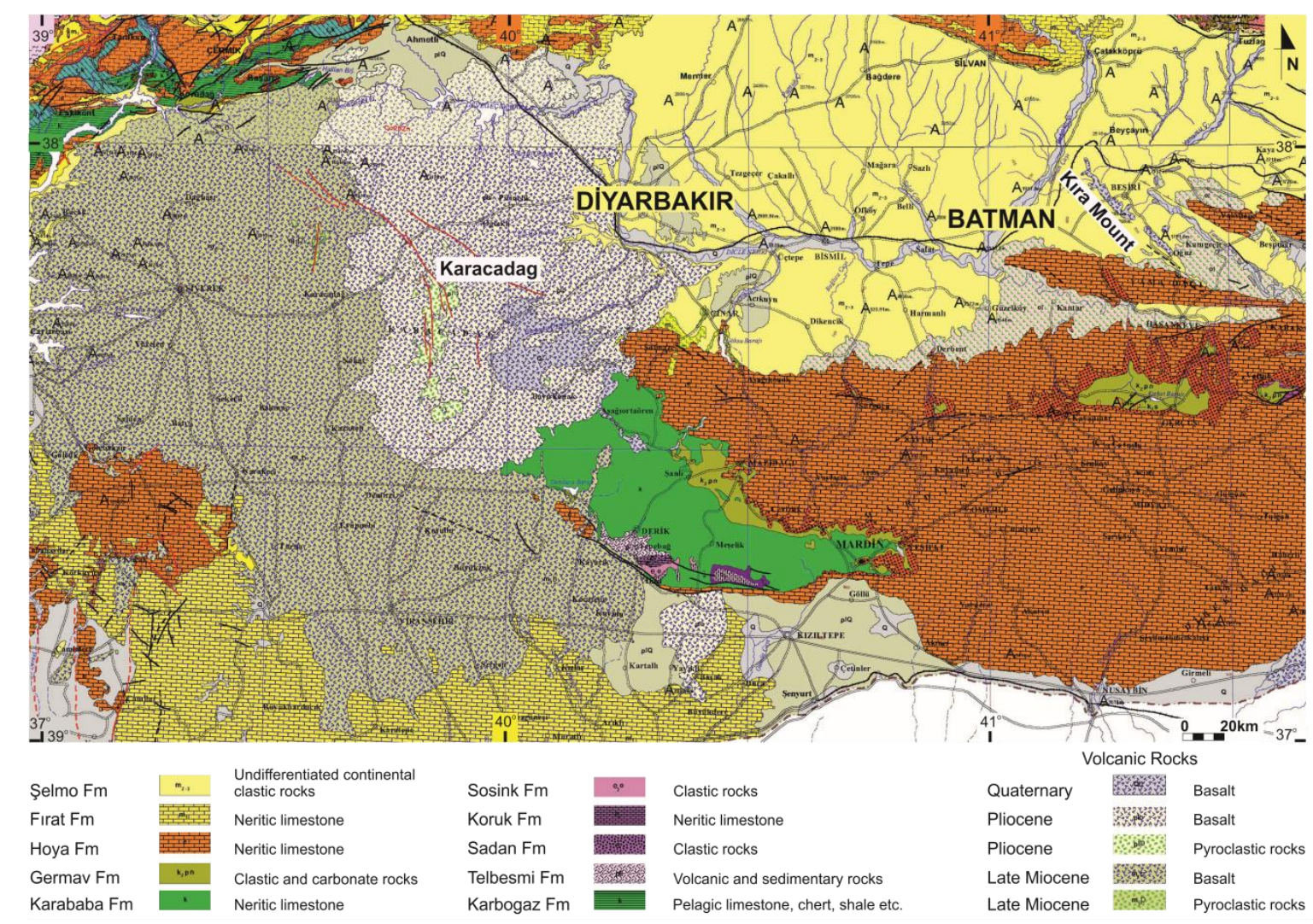

Figure 2. Geological map of the study area and its vicinity (the regional geology map is modified from [12])

\section{Analytical techniques}

In addition to the geological and topographical maps of the study area and its surroundings, more than 100 representative samples were collected by using satellite data. Thin sections were prepared in different university laboratories for petrographical studies from selected samples. Thin sections were examined by Leica DM750P brand under polarized microscope and detailed petrographic determinations were made especially mineralogical composition and textural features. For geochemical data, major oxides, trace elements and rare earth element analyzes were performed at the laboratories of ACME (Canada) and Istanbul Technical University. Each sample was weighed between $0.1 \mathrm{~g}$ and $1 \mathrm{~g}$ and subjected to a solution of HCF: HNO3: $\mathrm{HF}(3: 1: 0.5)$ acid mixture at a temperature of $180{ }^{\circ} \mathrm{C}$ and a pressure of 20 bar at the Berghof brand microwave. Fully soluble analyte solutions were analyzed on a Perkin Elmer ELAN DRC-e brand ICP-MS, Perkin Elmer Analyst 700 AAS device. Multi-element ICPMS calibration solutions at $10 \mathrm{mg} / \mathrm{L}$ concentration were used as calibration solutions.

\section{3. The geology of the investigated field}

\subsection{Kura mount volcanics}

The volcanics which can be traced along the Beşiri (Batman) district and nearby villages have a plateau basalt character and layer thickness reaches $40 \mathrm{~m}$. Considering the land spread (about $23 \mathrm{~km} 2$ ), 
there are no pyroclastic material exits. The color and textural characteristics of basaltic magma show occasional changes, and the presence of aggregates with gas porosity or column shape is noteworthy. Volcanites, where limited samples of basalt lava morphology are observed, can be distinguished from Karacadag volcanics in the field observations with abundant fractures and widespread discontinuities. In the scope of phenocrystalline, feldspar minerals (sanidine and plagioclase) are added to olivine, pyroxene and opaque minerals. Minerals are generally not euhedral, but they offer examples of alteration at different scales. Opaque minerals are commonly found in sections, while the feldspar bars in the matrix give typical basaltic texture samples (Figure 3).
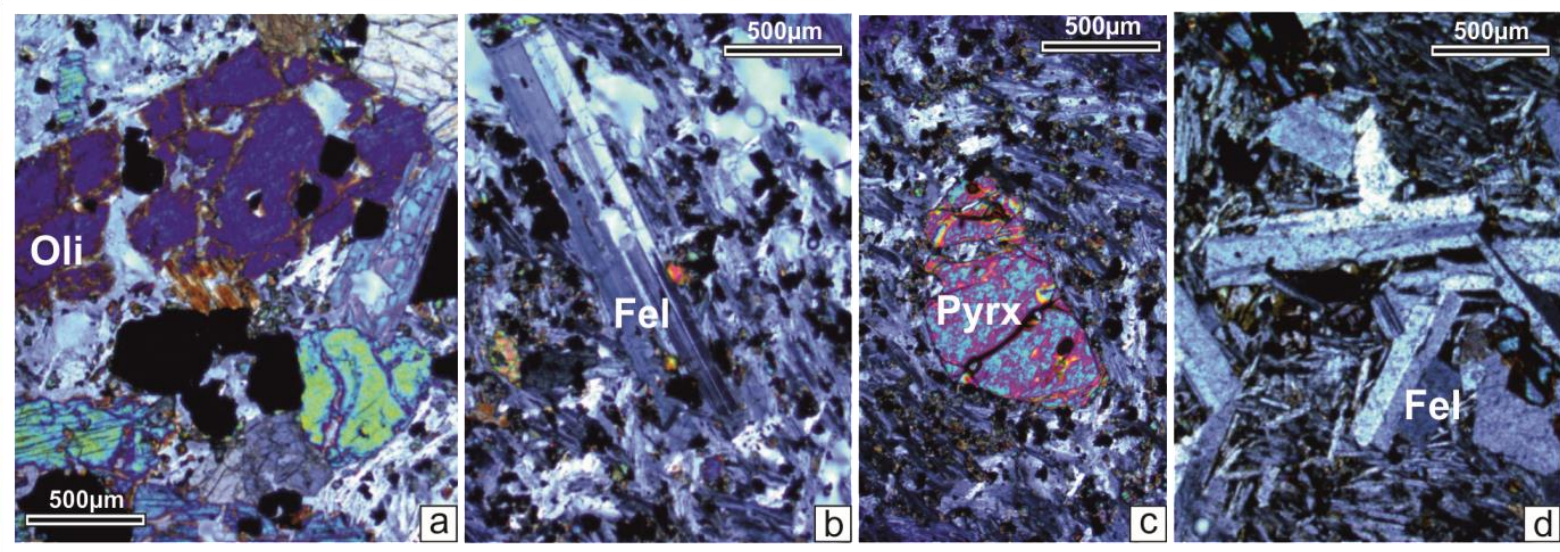

Figure 3. The Kura Mount volcanics generally show basaltic texture as euhedral or subhedral phenocrysts. a) Sample 1.1; Hypidiomorphic macrocrystalline olivines, microcrystalline pyroxene and opaque mineral grains in hypocrystalline porphyritic texture b) Sample 4a.2; plagioclase laths with polysynthetic, lamellar twins with lots of opaque minerals c) Sample $4 \mathrm{~b} .3$; the coloured crystal is pyroxene and the rest of the field is occupied by plagioclase microlites, high relief small opaque minerals and small pyroxene remnants in hypocrystalline texture d) Sample E4b-7, showing porphyritic texture, euhedral feldspar phenocrysts are seen in dense groundmass with abundant plagioclase microliths. (Oli: olivine, Fel: feldspar, Pyrx: pyroxene and all samples given above are trachy-basalt)

\subsection{Karacadag volcanics}

Karacadag volcanism, which is located in a very wide geography (about $10000 \mathrm{~km} 2$ ) covering different provinces of Mardin and Şanlıurfa, mainly in Diyarbakır, has been active in three main stages $[3,4]$. The most widely distributed and relatively oldest Siverek stage (2.7 Ma-11 Ma/constitutes 80\% of the volcanism) was the north-south direction from the south of Ergani to Viransehir. The Karacadag stage (1 Ma- 1,9 Ma/constitutes $15 \%$ of the volcanism) composes the main body of Karacadag and contains pyroclastic aggregates in some places. The youngest member, the Ovabag stage $(0,01 \mathrm{Ma}-0,4$ $\mathrm{Ma} /$ constitutes $5 \%$ of volcanism), has reached the SE directional surface, not in the form of a whole, but in several parts of the opening cracks. The phenocrysts of these volcanics include olivine, pyroxene (clinopyroxene), feldspar (plagioclase) and opaque minerals [10, 11, 12].

\subsection{Geochemical properties}

The major oxides, trace elements and REE of the Kira Mountain volcanics and the Karacadag volcanic complex (Table 1 and Table 2) were evaluated in the TAS diagram proposed by Le Bas et al. (1986) [9]. (Data related to the Karacadag volcanites are described in [3, 10, 11, 12] ). The main oxide changes reflect a characteristic of the sodic composition rich in $\mathrm{TiO} 2$, which is commonly seen around the Mediterranean when both volcanic products are considered together. The samples belonging to Karacadag show a wide distribution up to basalt and trachy-andesite including trachy-basalt, tefrite, 
phonotephrite, basanite, basaltic trachy-andesite, and alkaline character except for a few examples according to Irvine and Baragar 1971 [6] (Figure 4).

Table 1. Major oxide values of Kıra Mount volcanites and Karacadag volcanic complex (\%)

\begin{tabular}{|c|c|c|c|c|c|c|c|c|c|c|c|c|}
\hline & & $\mathrm{SiO}_{2}$ & $\mathrm{Al}_{2} \mathrm{O}_{3}$ & $\mathrm{Fe}_{2} \mathrm{O}_{3}$ & $\mathrm{MgO}$ & $\mathrm{CaO}$ & $\mathrm{Na}_{2} \mathrm{O}$ & $\mathrm{K}_{2} \mathrm{O}$ & $\mathrm{TiO}_{2}$ & $\mathrm{P}_{2} \mathrm{O}_{5}$ & $\mathrm{MnO}$ & $\mathrm{Cr}_{2} \mathrm{O}_{3}$ \\
\hline \multirow{2}{*}{$\begin{array}{l}\text { Kura } \\
\text { Mount }\end{array}$} & $(\min )$ & 46,30 & 13,74 & 13,90 & 3,48 & 7,20 & 3,84 & 1,44 & 3,44 & 1,56 & 0,21 & 0.047 \\
\hline & (mak) & 47,60 & 14,41 & 15,02 & 4,16 & 8,97 & 4,36 & 1,52 & 3,61 & 1,67 & 0,24 & 0.117 \\
\hline \multirow{2}{*}{ Karacadağ } & $(\min )$ & 43,27 & 11,35 & 6,82 & 4,40 & 4,57 & 2,31 & 0,43 & 1,18 & 0,02 & 0,12 & 0,00 \\
\hline & (mak) & 61,50 & 18,17 & 15,83 & 11,36 & 13,17 & 5,42 & 3,25 & 4,76 & 1,28 & 0,26 & 0,07 \\
\hline
\end{tabular}

Table 2. Trace elements and REE values of Kura Mount volcanites and Karacadag volcanic complex (ppm)

\begin{tabular}{|c|c|c|c|c|c|c|c|c|c|c|c|c|c|}
\hline & & $\mathrm{Rb}$ & $\mathrm{Sr}$ & $\mathrm{Ba}$ & $\mathrm{Sc}$ & $\mathrm{V}$ & $\mathrm{Cr}$ & $\mathrm{Co}$ & $\mathrm{Ni}$ & $\mathrm{Y}$ & $\mathrm{Zr}$ & $\mathrm{Nb}$ & $\mathrm{La}$ \\
\hline \multirow{8}{*}{ 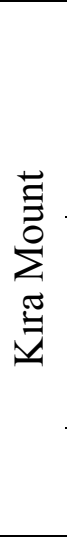 } & $(\min )$ & 21,9 & 361,1 & 385 & 28 & 171 & 320 & 25,5 & $<20$ & 45,3 & 250,6 & 16,5 & 34,2 \\
\hline & $(\max )$ & 29,3 & 498,8 & 544 & 29 & 189 & 800 & 34,8 & $<20$ & 51 & 268,8 & 18,2 & 36,9 \\
\hline & & $\mathrm{Ce}$ & $\operatorname{Pr}$ & $\mathrm{Nd}$ & $\mathrm{Sm}$ & $\mathrm{Eu}$ & $\mathrm{Gd}$ & $\mathrm{Tb}$ & Dy & Ho & $\mathrm{Er}$ & $\mathrm{Tm}$ & $\mathrm{Yb}$ \\
\hline & $(\min )$ & 76,8 & 10,49 & 47,5 & 10,73 & 4,2 & 11,28 & 1,67 & 9,25 & 1,82 & 4,82 & 0,62 & 3,79 \\
\hline & $(\max )$ & 82,6 & 11,27 & 51,1 & 11,62 & 4,49 & 12,13 & 1,85 & 10,73 & 1,97 & 5,27 & 0,68 & 4,44 \\
\hline & & $\mathrm{Lu}$ & Th & $\mathrm{Pb}$ & $\mathrm{U}$ & $\mathrm{Hf}$ & $\mathrm{Ta}$ & $\mathrm{Ga}$ & Cs & $\mathrm{Cu}$ & $\mathrm{Zn}$ & & \\
\hline & $(\min )$ & 0,52 & 3,8 & NA & 0,6 & 5,2 & 1 & 19,5 & $<0,1$ & 25,99 & 167 & & \\
\hline & $(\max )$ & 0,63 & 4,7 & NA & 1,7 & 6,1 & 1,4 & 22,1 & 1,1 & 48,53 & 203,1 & & \\
\hline \multirow{9}{*}{ 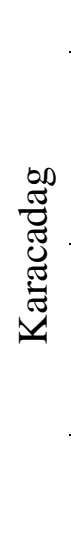 } & & $\mathrm{Rb}$ & $\mathrm{Sr}$ & $\mathrm{Ba}$ & $\mathrm{Sc}$ & V & $\mathrm{Cr}$ & $\mathrm{Co}$ & $\mathrm{Ni}$ & $\mathrm{Y}$ & $\mathrm{Zr}$ & $\mathrm{Nb}$ & $\mathrm{La}$ \\
\hline & $(\min )$ & 3,30 & 412 & 147 & 18,0 & 142 & 60 & 26,0 & 57 & 18,8 & 112,0 & 14,1 & 9,83 \\
\hline & $(\max )$ & 33,0 & 1160 & 543 & 25,00 & 263 & 460 & 67,0 & 300 & 30,80 & 897 & 90 & 82,90 \\
\hline & & $\mathrm{Ce}$ & $\mathrm{Pr}$ & $\mathrm{Nd}$ & $\mathrm{Sm}$ & $\mathrm{Eu}$ & $\mathrm{Gd}$ & $\mathrm{Tb}$ & Dy & Ho & Er & $\mathrm{Tm}$ & $\mathrm{Yb}$ \\
\hline & $(\min )$ & 22,80 & 2,82 & 12,10 & 3,31 & 1,31 & 3,74 & 0,58 & 3,21 & 0,59 & 1,66 & 0,22 & 1,29 \\
\hline & $(\max )$ & 162 & 18,90 & 64,10 & 13,70 & 4,52 & 11,50 & 1,50 & 6,60 & 1,10 & 2,70 & 0,36 & 2,11 \\
\hline & & $\mathrm{Lu}$ & $\mathrm{Th}$ & $\mathrm{Pb}$ & $\mathrm{U}$ & $\mathrm{Hf}$ & $\mathrm{Ta}$ & $\mathrm{Ga}$ & $\mathrm{Cs}$ & $\mathrm{Cu}$ & $\mathrm{Zn}$ & & \\
\hline & $(\min )$ & 0,15 & 0,72 & 0,50 & 0,20 & 2,65 & 0,76 & 36,0 & 0,10 & 40 & 150 & & \\
\hline & $(\max )$ & 0,27 & 6,80 & 6,00 & 2,20 & 11,10 & 7,10 & 20,1 & 0,80 & 100 & 260 & & \\
\hline
\end{tabular}

Although it is noteworthy that the Kira Mountain lavas are falling into the trachy-basalt, tephrite, phonotephrite, and basanite range, it is determined that they have an alkaline character such as Karacadag products. In order to examine the main oxide data carefully, Kira Mountain volcanics show lower values of $\mathrm{SiO}_{2}, \mathrm{Al}_{2} \mathrm{O}_{3}, \mathrm{MgO}, \mathrm{CaO}, \mathrm{Na}_{2} \mathrm{O}, \mathrm{K}_{2} \mathrm{O}$ and $\mathrm{TiO}_{2}$ compared to Karacadag products whereas $\mathrm{Fe}_{2} \mathrm{O}_{3}$ and $\mathrm{MnO}$ data are considered as equivalent on average. With respect to the $\mathrm{P}_{2} \mathrm{O}_{5}$ and $\mathrm{Cr}_{2} \mathrm{O}_{3}$ values, an enrichment is observed.

It is seen that the rising basalts, mostly Siverek stage volcanics and Karacadag stage volcanites, predominantly alkaline character Karacadag products imply the $\mathrm{Nb} / \mathrm{La}(>1)$ and $\mathrm{Nb} / \mathrm{Yb}$ ratios showing a scattered trend and the OIB type as the asthenospheric mantle. In contrast, the lower $\mathrm{Nb} / \mathrm{La}(<1)$ and low $\mathrm{Nb} / \mathrm{Yb}(<8)$ values of the Kira Mountain volcanics indicate that the mantle source they derive is 
interacting with each other on the basis of the mixed lithospheric-astenosphere mantle, which is a strong evidence of the heterogeneity of the mantle source (Figure 5).

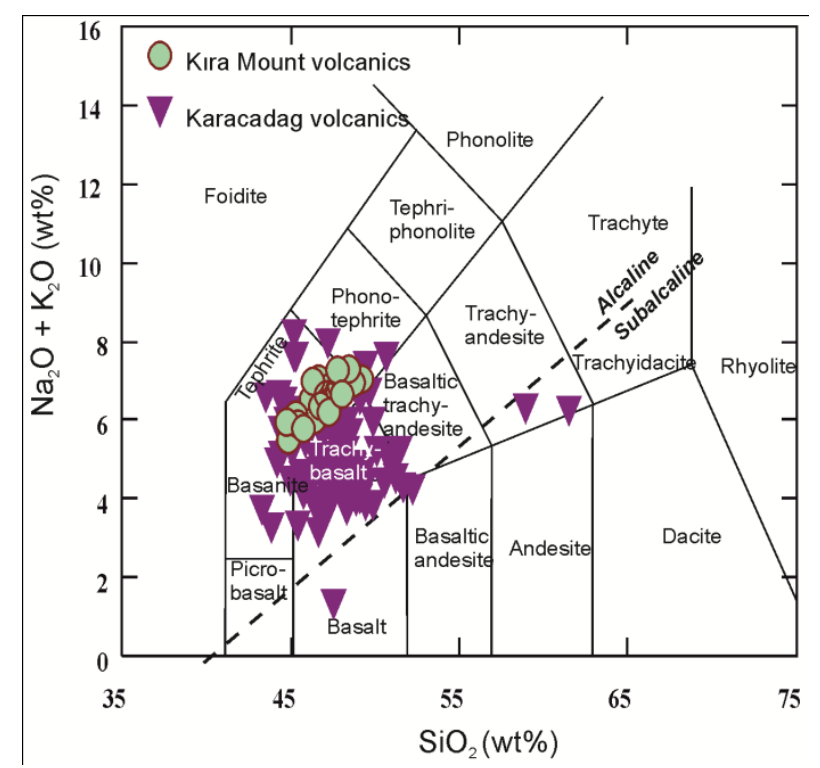

Figure 4. TAS diagram [9] and geochemical characteristics [6] of Kıra Mount volcanics and Karacadag volcanics

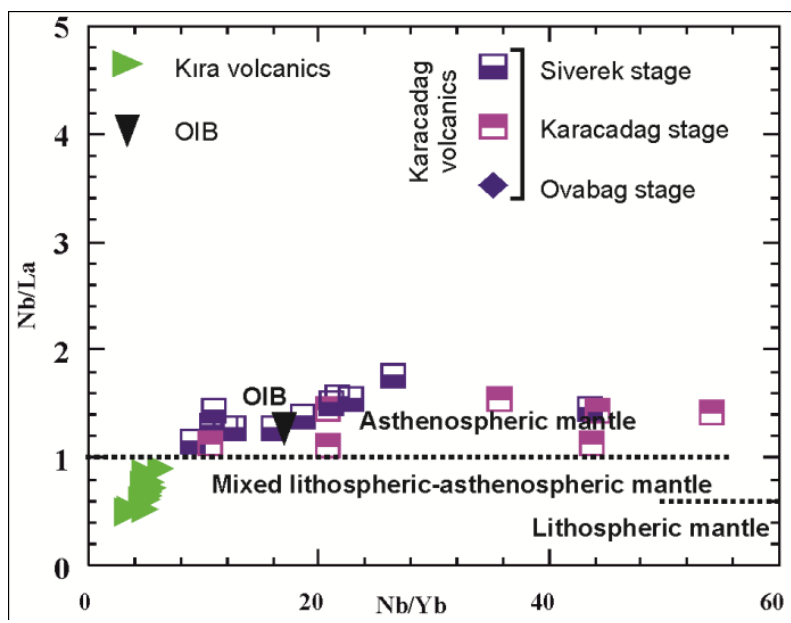

Figure 5. Nb/La-La/Yb diagram of Kira Mount volcanics and Karacadag volcanics [1]

\section{Discussion}

To take regionally, the collision of the Arabian and Anatolian plate, which controls the neotectonics Turkey is one of two main events and has played a decisive role in terms of the dynamics of this case. This movement formed an in-plate volcanism that started in Late Miocene and continued until Quaternary and thus formed Karacadag and Kıra Mountain. Karacadag lava coming out of the opening cracks and reaching the surface in the direction of NW-SE is in line with the Kira Mountain lava. The Karacadag products also show formations in the N-S direction. While the Kira Mountain volcanites are classified as tephrite, phono-tephrite, trachy-basalt and basanite, the Karacadag magma also offers a wide distribution extending from basalt to trachy-andesite. Karacadag products are similar 
to OIB and are predominantly of asthenospheric mantle origin. In contrast, the magma forming the Kira Mountain marks a mixed lithospheric-astenospheric mantle composition.

\section{Conclusion}

On the basis of the stratigraphic location of the region for many years, the Kura Mountain volcanics have been evaluated as Pliocene and some have been accepted as Quaternary in literature studies. Nonetheless, in the light of the current geological data, with the effect of the stress regime developed due to neotectonic deformation in the region, mantle uplift was realized and basaltic products were exposed in plateau basalt form spreading in Diyarbakır and Batman regions. Although the Kira Mountain lavas exhibit similar mineral paragenesis, they can be distinguished from the Karacadag Volcanites by their abundant fractures and widespread discontinuities in the field surveys as well as by their distinctive color distribution in different shades. Considering the unique contribution of analysis data, it is quite clear that the Late Miocene aged Kira Mountain volcanites were found in the Karacadag volcanites which correspond to Siverek stage periodically, exhibit different geochemical characteristics and derived from different types of magma.

\section{References}

[1] Abdel-Rahman, A.M., Mesozoic Volcanism in the Middle East: Geochemical, Isotopic and Petrogenic Evolution of Extension Related Alkali Basalts from Central Lebanon. Geological Magazine 139/6 (2002), pp. 621-640

[2] Canpolat, E., Geomorphology of Karacadag (Diyarbakır) Volcano, Master Thesis, Istanbul University Institute of Social Sciences Department of Geography, Istanbul, Turkey, 2005

[3] Ekici, T., Macpherson, C. G., Otlu, N., Polybaric Melting of a Single Mantle Source During the Neogene Siverek Phase of the Karacadag Volcanic Complex, SE Turkey, Lithos (2012), 146-147, pp. $152-163$

[4] Ekici, T., Macpherson, C. G., Otlu, N., Fontignie, D., Foreland Magmatism During the ArabiaEurasia Collision: Pliocene-Quaternary Activity of the Karacadag Volcanic Complex, SW Turkey, Journal of Petrology Volume 55 (2012)., Number 9, pp. 1753-1777

[5] Ercan, T., Şaroğlu, F., Turhan, N., Matsuda, J. I., U, T., Fujitani, T., v.d., Geology and Petrology of Karacadag Volcanites. Bulletin of the Geological Society of Turkey, S 6 (1991), pp. 118-133

[6] Irvine, T. N., Baragar, W. R. A., A Guide to the Chemical Classification of the Common Volcanic Rocks. Canadian Journal of Earth Sciences 8 (1971), pp. 523-548

[7] Kalkan, Ö., Petrogenesis of the Basalts of Kıra Mount (Batman), Master Thesis, Batman University Graduate School of Natural and Applied Sciences, Batman. Turkey, 2014

[8] Kavak, O., Diyarbakır ve Çevresinde Yer Alan Karacadag Volkaniti'nin Genel Özellikleri. (General properties of Karacadag Volcanite in Diyarbakir and its Surroundings), Karacadag and the Book of Environment, Uzman Printing, Page 361-372, Diyarbakır, Turkey, 2013

[9] Le Bas, M.J., Le Maitre, R.W., Streckeisen, A., Zanettin, B., A Chemical Classification of Volcanic Rocks Based on the Total Alkali-Silica Diagram. Journal of Petrology 27 (1986), pp. 745-750 
[10] Lustrino, M., Keskin, M., Mattioli, M., Lebedev,V. A., Chugaev, A., Sharkov, E., Kavak, O., Early Activity of the Largest Cenozoic Shield Volcano in the Circum-Mediterranean Area: Mt. Karacadag, SE Turkey. European Journal of Mineralogy 22 (2010), pp. 343-362

[11] Lustrino, M., Keskin, M., Mattioli, M., Kavak, O., Heterogeneous Mantle Sources Feeding the Volcanic Activity of Mt. Karacadag (SE Turkey), Journal of Asian Earth Sciences 46 (2012), pp. $120-139$

[12] MTA, 2002. 1/500 000 Scale Geological Map of Turkey, Diyarbakır, Ankara

[13] Şengör, A. M. C. and Yılmaz, Y. Tethyan evolution of Turkey: A Plate Tectonic Approach. Tectonophysics, 75 (1981), pp. 181-241.

[14] Okay, A. I., Şengör, A. M. C. and Görür, N. 1994. Kinematic History of the Opening of the Black Sea and its Effects on Surrounding Regions. Geology, 22 (1994), pp. 267-270.

[15] Okay, A.I., 2008; Geology of Turkey: A synopsis. Anschnitt, Zeitschrift für Kunst und Kultur im Bergbau, Beiheft 21, 19-42. Veröffentlichungen aus dem Deutschen Bergbau-Museum Bochum, Nr. 157.

[16] Yeşilova, C.., Helvac1, C., Stratigraphy and Sedimentology of the North of Batman-Siirt, Bulletin of TPDJ, Volume 23 (2012), Issue 2, pp. 7-49

[17] Yeşilova, G. P., Helvacı, C., Diagenesis and Paleogeographic Development of Oligocene Evaporites (Kurtalan, SW Siirt) in Germik Formation, Hacettepe University Earth Sciences Application and Research Center Bulletin, 34/1 (2013), pp. 1-22 